\title{
IMPACT OF EMPLOYEE DEVELOPMENT IN AGRICULTURAL COMPANIES ON COMMITMENT, LOYALTY AND PERFORMANCE
}

\author{
Hana Urbancovál, Lucie Vnoučkováa \\ 'Department of Territorial Development of Agriculture and Rural Areas, Division Research - Rural Development, \\ Institute of Agricultural Economics and Information, Mánesova 1453/75, 12000 Prague 2, Czech Republic \\ ${ }^{2}$ Department of Management, University of Economics and Management, Nárožní 2600/9a, 15800 Prague 5, \\ Czech Republic
}

\begin{abstract}
URBANCOVÁ HANA, VNOUČKOVÁ LUCIE. 2018. Impact of Employee Development in Agricultural Companies on Commitment, Loyalty and Performance. Acta Universitatis Agriculturae et Silviculturae Mendelianae Brunensis, 66(3): 803-811.

Employees in agricultural companies are aware of the necessity to learn and develop; hence it is essentially easier for the agricultural companies to encourage their employees to engage in these processes. Regardless the awareness of the employees concerning the development, the organisational features of the agricultural companies, which influence the development of the employees, needs to be taken into account. The aim of the paper is to identify the attitude of surveyed agriculture organisations towards employee development and to evaluate possible use of employee development strategies impacting employee commitment, loyalty and performance. Data were collected by means of quantitative research in selected number of agricultural companies $(\mathrm{n}=101)$ in the Czech Republic, while the data were evaluated by descriptive (correlation) analysis and multidimensional statistics (factor analysis). Results show that employee development foster commitment, loyalty and performance. The results were able to classify the HR systems of the case organisations into six types according to factor analysis: external HR marketing, internal development, investments into development, increased loyalty and competitiveness, increased understanding and finally, increased retention based on loyalty and commitment. Furthermore, smaller companies often lack formal development. On the contrary, large and micro companies have exact practices and outputs related to it.
\end{abstract}

Keywords: agriculture, employee development, talent, skill, commitment

\section{INTRODUCTION}

In contemporary competitive environment, it is necessary for each company, regardless its field of activity, to pay attention to employee training and development, which helps not only increase the productivity of work, exploitation of new knowledge and better motivation of the employees to co-operate on innovations, but also the development of entire company. Through employee training and development, the employers may find new effective ways to acquire source competitive advantage and $\mathrm{Li}$ and Liu (2014) adds that the only competitive advantage is the holders of knowledge. Increased working potential consequently affects all company processes in all companies, including agricultural ones, as confirmed by research of Kragulj (2016), where it was proved that employee development causes organisational changes, effectively exploits knowledge and creates new ones. Diaz-Fernandez et al. (2017) adds that the companies need to adapt to the changes and support their development as well as employee development for strategic development. 
The results of Diaz-Fernandez et al. (2017), Barao et al. (2017), Kragulj (2016), Seuneke et al. (2013) etc. showed that companies, regardless the sector, are constantly exposed to series of external influences, characteristics and situations, which all the more emphasises the need to adapt the employee knowledge to the strategic development of the company - a view shared by e.g. Li and Liu (2014); Razak et al. (2016); Seuneke et al. (2013). With regard to the above mentioned it can be summarised that if management creates suitable conditions for the employees and further manages them and controls the development process, the synergic effect within the development of individuals and entire company can be achieved, regardless the business sector.

Literature in past years often focuses on determinants of organizational performance (i.e. Munday et al., 2003; Griffith and Simpson, 2004). The same interest catches organisational commitment. Nevertheless, employee, company and workplace performance is dependent on many determinants. For example, employee commitment and loyalty are core variables and they are seen as mediating factors linking different types of human resource management and employment practices to enhanced performance (Brown et al., 2011). Therefore, it is important to analyse other factors that determine or may influence final performance. In this paper, we focus on aspects of employee development and their impact on performance using employer data. Furthermore, we explore impact of employee development on commitment and loyalty and financial performance at the company level. In addition, we explore the factors which are used by organisations in order to find possible approaches to employee development and benefits attached to it (Held, 2016).

This research aims to investigate and find the ways how to develop the employees and talents developed $n$ agriculture sector and how to satisfy their needs for development. The aim of the paper is to identify approaches of surveyed agriculture organisations towards employee development and to evaluate possible use of employee development strategies impacting employee commitment, loyalty and performance.

This paper explores mechanisms on how companies and employers in agriculture sector may access and retain reliable employees by training and development. To hire and train new employees is a major expense and have to be managed very carefully to maintain economic efficiency. Therefore, it is necessary to count with investments to retain current labour force instead of continuous fluctuation with higher costs of labour in companies. However, the critical component to successful employee retention is their satisfaction gained not only by rewards, but also development.

The paper contains six sections. Firstly, Introduction to the subject and issue is presented, followed by the Theoretical Background containing presentation of the current state of related theory and similar research. The methodological approach is presented in chapter Materials and Methods. Subsequently, the analysis of the subject is discussed in the Results and Discussion chapter. Finally, authors conclude the paper and summarise the contributions and limitations of the paper in the Conclusions and point out some ways for future research in this area.

\section{Theoretical Background}

Economic theory describes labour as a source for organisational performance accessible on labour market. The labour market offers companies and employees to meet and fill their needs for rewards in the case of employees and performance desired by companies. As mentioned before, agriculture is less desired sector for employees because of its underestimated payment and salary conditions, precarious work systems, seasonal contracts and unfavourable work conditions (Schuler and Jackson, 1987; Kroon and Paauwe, 2014). Ethical rules suggest not seeing labour only as a factor or commodity, but as human beings, and that employees should be treated with respect. These ethical principles should restrict only the economic considerations in managing labour. Therefore, employment is necessary to be seen as two-side contract where both parties are equal and should be treated with respect and furthermore, to be encouraged and developed for future use. This refers to socially responsible HRM, where employees are seen as stakeholders and thus integral part of corporate social responsibility (Rowan, 2000; Simmons, 2008).

Each undertaking, with agricultural company not being an exception, needs to create appropriate organisational conditions to help effective employee development. These conditions and characteristics differ within individual companies. However, if the conditions are set correctly, the results achieve synergic effect. The results of Seuneke et al. (2013) or Šümane et al. (2017) show that the conditions for employee training and development significantly differ in individual companies.

The current continuous development of employee enhancement is crucial also in modern agriculture. All employees including low-skilled, engineering and technical positions have higher and more specialized requirements in terms of the competencies, skills and qualification (Xinyu et al., 2015). Agriculture corporations, companies and family farms still host large numbers of low or under-paid and often low-skilled job positions (Gauthié and Schmitt, 2010; Kroon and Paauwe, 2014). Not favourable employment conditions such as uncertainty about employment, dependence on weather, lack of employee voice and low wages are part of reasons why agriculture is at the end in the list of top employers (Appelbaum and Schmitt, 2009; Pena, 2010). However, it is possible to find organisations in which investments in employees and their development prevail over low-cost in each sector 
(Knox and Walsh, 2005; Edwards et al., 2009). The agriculture sector is characterised by heterogeneity in employment and employee development systems. At the same time, economic conditions lead to use of low-cost, precarious employment (Barrett and Rainnie, 2002; Edwards and Ram, 2006). On the other hand, one of the major challenges for employers in agriculture is accessing and retaining reliable, affordable employees (Janssen, 2013). This can be facilitated by employee development.

Employee training and development should ensure that each company, including enterprises active in agriculture, has employees of the quality needed for achievement of its goals, as confirmed by Razak et al. (2016) or Lee a Bruvold (2003). However, this can by achieved only if the employees have knowledge and skills necessary for effective work performance and its constant enhancement, which would maximise also their growth potential (Rastgoo, 2016; Razak et al., 2016; Lee, Bruvold, 2003).

Kim and Wiggins (2011) points out that human resource policy must respond to rapidly changing demographics, concerning the current increase of single unmarried youngsters, turning into middleage employees and huge number of elderly people in agriculture, as it is a major challenge to work and satisfy needs of those differentiated groups. Furthermore, compensation policy has stagnated for a long time and has focused on family-oriented values by promising increased capacity to provide for a family in exchange for higher work performance. It is no longer sufficient and employees desire new ways to be treated (Rastgoo, 2016; Razak et al., 2016). Therefore, HR policy has to focus on shifting preferences of the employees aiming at other characteristics which differ widely by demographic characteristics (Kim and Wiggins, 2011).

In this paper, we focus on employee development and its impact on commitment and performance. The term "commitment" is according to Meyer and Allen (1991, p. 67): “... employee's emotional attachment to, identification with, and involvement in the organisation." A Meyer et al. (2002) state, that commitment to an organization arises when employees share values with both the organisation and its employees and representatives and it is positively associated with performance. Moreover, fostering committed and loyalty in member staff is associated with company performance (Brown et al., 2011). This relationship between employee performance and commitment encourages to deeper investigation of development support, which may be according to literature fostering commitment, loyalty and performance. Furthermore, this hypothesis is supported by other scientific literature on human resource (HR) practices (i.e. Hughes and Rog, 2008; Wilden et al., 2010; Garavan et al., 2012; Marchington, 2015). Employees who demonstrate commitment and loyalty usually have interests that are in line with those of their employer organisation; which is fostered by identity and work incentives including development. This attachment to an organization is crucial for development of entire organisation (Akerlof and Kranton, 2005). With regard to importance of commitment, loyalty and its impact on performance, it is surprising that those concepts have attracted only limited attention in the literature. This paper outlines empirical study to deepen knowledge about the link between HR practices, especially employee development in agriculture and performance, commitment and loyalty.

\section{MATERIALS AND METHODS}

For the purposes of the research presented in this paper, our own database of agriculture and forestry companies was made, based on quota sampling. The quotas used to create the database were specified based on data and sampling of the Czech Statistical Office. The sampling used size of company, number of employees, type of company (all types were used for the sampling - corporates, cooperatives, state farms and family farms), and address and district of the farm or company in the Czech Republic. The database respects the proportion of size and type of companies in the Czech Republic. The database created for the purposes of this survey consists of 680 companies. The companies selected for the survey were contacted based on their registration in the database of agriculture and forestry companies operating in the Czech Republic. The overall questionnaire return was $14.8 \%$, i.e. 101 companies completed and returned the questionnaire. The Czech companies involved were mainly small-sized (60.4\%) including family farms; $32.7 \%$ were medium sized, while large companies (with more than 250 employees) made up $6.9 \%$. The sampling error was measured and the results are positive; it is possible to generalise the results.

The data were collected by means of using an electronic questionnaire which automatically recorded and pre-categorised respondents' answers (CAWI method - 85 respondents). The telephone interview (CATI) method was also used with 16 respondents. The sample selection took into account the size of the company (small companies of up to 50 employees; medium-sized companies employing between 51 and 249 people and large companies with more than 250 employees). Only respondents from upper or top management (HR managers were excluded) answered the questionnaire. Only one respondent per company was questioned.

The structure of agricultural companies taking into account the use of development strategy by HR and majority ownership was as follows:

- In total $38.6 \%$ of agricultural companies use build strategy (internal employee training and development), 20.8\% use bind strategy (binding talented employees), 5.9\% carry out buy strategy (hiring talents outside the company) and 2.0\% borrow strategy (the company hires skilled talents only for limited period of time), in total $32.7 \%$ of agricultural companies do not have any development strategy set up; 
- Agricultural companies with Czech majority ownership made up 93.1\%, those with foreign majority ownership $6.9 \%$ in total.

The respondents addressed individual statements based on the theoretical perspectives of the work and indicated their agreement or disagreement. They also had the opportunity not to answer in the event that the given statement was not relevant to their company.

The respondents' answers were classified according to identification questions that constituted the first section of the questionnaire. Measurements in the survey were derived from closed questions with one or several possible answers that had been selected based on the study of literature, documents and other related surveys. The semantic differential was also applied.

All the primary data were evaluated using descriptive statistics and correlation analysis using Cramer's V (De Vaus, 2014). Further analyses were based on the method of multidimensional statistics - factor analysis. The factor analysis was conducted to find groups of responses of students regarding their perception. The goal was to find groups of variables with significant appearance and consistent content and at the same time to reveal main orientation of coherent groups of respondent organisations in the field of employee development. The higher level of generalisation of results by factor analysis helps to focus on the most important and highly recommended areas while filtering out inconsistencies (which may be studied separately as outstanding values which in turn, may also be inspiring for development).

The analysis is often used in social sciences (Hebák et al., 2014; Palát, 2012). The method is used quite often and favoured by researchers also in the area of development research (Anderson, 2009). The levels of correlation coefficients were sufficient according to Anderson (2009) and Hendl (2012) to enter factor analysis. Moreover, $86 \%$ of correlations in the correlation table were statistically significant. The KMO (Kaiser-Meyer-Olkin test) value reached over 0.79 which is considered as meritorious and thus adequate for factor analysis.

The number of monitored variables (factors) was reduced using the Varimax method. For the selection of substantial factors the Kaiser-Guttman rule was applied (i.e. substantial factors having a value within the range higher than 1) and subsequently Sutin test was applied. The correlation coefficients are in the interval from $\langle-1 ; 1\rangle$. If the correlation coefficient is positive, it is a direct proportion (negative - indirect proportion). For the evaluation, the value of variable correlation higher than 0.3 (moderate correlation) according to Anderson (2009) was used.

To evaluate the data, the IBM SPSS 22 Statistic and MS Excel 2007 were used. During the research the following procedures were in accordance with ethical standards and Czech law relating to the use of sensitive information.

\section{RESULTS}

The results show that surveyed companies are focused mainly on their own employees and their training and development. Other strategies are not well known and used yet. Taking into account the evaluated data it can be summarised that 78,2 \% of addressed agricultural companies do not use talent pool, which may be caused e.g. by lack of best practice in the area of talent identification within as well as outside the company. The representatives of the companies from the primary sector were interviewed what they emphasise in employee development, whether it is interpersonal skills or knowledge in the field of agriculture and forestry. The results indicate that $69,3 \%$ of the addressed representatives of the companies reported that both groups are equally important for meeting the requirements of the posts in given economy sector. In total $24,8 \%$ of representatives reported that hard skills, i.e. knowledge in the field of work and expertise of the employee are the most important. Only 5,9 \% of the addressed representatives of the companies reported that the most important are interpersonal skills. Frequencies of the characteristics of the agricultural companies in employee development are listed in Tab. I.

Surveyed agricultural companies see benefits of employee development, i.e. attractiveness of a company for external workers and talents, impact of employee development on profits, lowering costs, increased trust, commitment, retention, motivation, loyalty, performance and competitiveness. On the other hand, it is possible to seen be seen that the surveyed companies mainly point out the benefits of employee development, but do not have any budget for research or development and this area is managed randomly or without any investment.

Furthermore, Tab. I contains results of tested hypotheses focusing on correlation between selected variable and size of a company. The correlations were tested by Cramer's V. All correlation coefficients are significant at the level of 0.05 . The " $\mathrm{x}$ " in the table symbolises unfulfilled conditions for testing.

As can be seen in Tab. I, most of the variables correlate with the size of a company. Employee development in surveyed agriculture companies differ according to their size. The results of analyses imply that large companies, as well as the small and micro ones pay more attention to employee development and characteristics related to employee and talent retention characterised by variables listed in the Tab. I.

According to the representatives of the companies, employee development significantly affects trust between employees and supervisors, their motivation and lowers employee turnover.

To verify the results obtained by the research focused on agricultural companies, the data were further tested by multidimensional statistics by 
I: Frequencies of the characteristics of the agricultural companies in employee development

\begin{tabular}{|c|c|c|}
\hline $\begin{array}{l}\text { Characteristics of the agricultural companies in employee } \\
\text { developments }\end{array}$ & Absolute frequencies & Cramer's V \\
\hline External workers have a strong interest in working for the company & 17 & 0.326 \\
\hline Company is attractive for talents & 10 & $\mathrm{x}$ \\
\hline $\begin{array}{l}\text { There is no budget for development/research, the field is solved } \\
\text { operationally }\end{array}$ & 22 & 0.682 \\
\hline $\begin{array}{l}\text { There is no budget for development/research, the company does not } \\
\text { invest in the filed }\end{array}$ & 14 & $\mathrm{x}$ \\
\hline Innovations are created, implemented and used in the company & 15 & $\mathrm{x}$ \\
\hline Employee development increases income & 26 & 0.357 \\
\hline Employee development minimises costs & 19 & 0.285 \\
\hline Employee development improved communication with customers & 25 & 0.247 \\
\hline Employee development enhanced motivation of employees & 15 & 0.448 \\
\hline Employee development enhanced trust between managers and staff & 19 & 0.886 \\
\hline Employee development enhanced employee loyalty & 17 & 0.295 \\
\hline Employee development lowered turnover & 14 & 0.668 \\
\hline Employee development enhanced employee performance & 22 & 0.366 \\
\hline Employee development enhanced overall performance & 34 & 0.315 \\
\hline Employee development enhanced competitiveness & 16 & 0.309 \\
\hline
\end{tabular}

Source: own survey

means of factor analysis, operating with identified variables. The values calculated in factor analysis express according to Anderson (2009). The results identified 6 significant factors meeting the criteria set by the methodology. The identified factors explain in total $42.96 \%$ of the sample behaviour or the possibilities of resulting characteristics (Tab. II).

First factor brings together the companies which focus on recruitment of new employees and external workers, while being attractive for external workers. A quality external HR marketing in form of attracting new employees may be presumed here. The coefficients found are of relatively hich quality. The factor may be named External orientation of the company. In total, $8.88 \%$ of surveyed companies focus on external human resource marketing. The second factor is completely opposite to the first one. It characterises the companies which rarely recruit new employees, on the contrary, they focus on development of the current ones. Moreover, these companies demonstrate enhanced performance based on employee development activities. The second factor is $8.23 \%$ of the sample. Thirdly, factor 3 describes $7.44 \%$ of surveyed companies and can be described by increasing costs and investments into employee development. Quite opposite is the fourth factor. It characterises responses of the companies (7\%) which experiences enhanced employee loyalty and competitiveness as a result of employee development. The fourth factor shows that employee development has a significant impact on employee loyalty and company performance. In line with factor 4 is also factor 5 which is characterised by expression of loyalty and increased understanding and cooperation, good relationships and trust between managers and staff. Again, it is possible to support the theory in the statement that employee development significantly impacts loyalty and commitment. Furthermore, according to the factor 4, employee development significantly impacts performance too. Finally, factor 6 shows link to talent management, as it brings together the companies which attract talents and demonstrate increased retention, loyalty and commitment of employees based on employee development. In the summary, it is possible to find impact of employee development on performance, commitment and loyalty in multiple factors. Surveyed companies mainly perceive these benefits of employee development and the analysis confirmed significant relationships between those variables.

Nowadays, it is mainly planned career advancement or shift, which is the reason for development and it applies also to agricultural companies. Therefore it is advisable for agricultural companies to focus on setting up career plans, programs, pool etc. Agricultural companies, as well as other enterprises in national economy, can no longer look for the employees, technicians, specialists and managers on labour market, since they can hardly be found there. First, due to low unemployment, secondly, due to high costs of such workers. Thus it is more appropriate to educate own skilled employees (talents) and to adapt the company culture to it.

It is therefore to reasonable to expect increasing use of talent programs, career plans and use of talents, which is obviously positive also for the employees. They have a real opportunity to develop, if they show their interest and are willing to participate in their development. 


\section{DISCUSSION}

Employee development is important for all types of enterprises, not excluding the agricultural ones. The results achieved identified the importance of employee development strategy in agricultural companies and the need of hard and soft skills development, supporting strategic development of entire company. These results are supported by the conclusions of research of Li and Liu (2014) or Diaz-Fernandez et al. (2017).

With regard to growing pressure towards higher qualification requirements in agricultural sector, the development, as well as self-education, is necessary. Over time, the employee, unwilling to educate and develop and improve his knowledge, abilities and skills, becomes a holder of outdated working processes, which may affect the competitiveness of entire company, while his potential is decreasing, but the costs of his employment, incurred by the company, remain the same.
The results of the survey showed that the company performance of the addressed agricultural companies is affected by many determinants such as Investment in HR, Loyalty, Coherence, or Talent management application, which is in accordance with the results of research by Brown et al. (2011). However, these determinants need to be constantly analysed and the results to be applied in the development strategies of entire agricultural company in the field of HR activities, which is confirmed also by the results of Seuneke et al. (2013). It is very important to know the mechanisms how companies and employers in agriculture sector may acquire and retain reliable employees by training and development and therefore this paper focuses on this topic. Taking into account the results of the factor analysis conducted, it is possible to support the results of the research by Rowan (2000) and Simmons (2008), who emphasise the socially responsible HRM where employees are seen as stakeholders and thus integral part of corporate social responsibility.

II: Resulting factors by the Varimax method

\begin{tabular}{|c|c|c|c|c|c|c|}
\hline Variable/Factor & 1 & 2 & 3 & 4 & 5 & 6 \\
\hline $\begin{array}{l}\text { Company recruits new } \\
\text { employees }\end{array}$ & 0.823 & 0.079 & 0.146 & 0.024 & 0.089 & 0.052 \\
\hline $\begin{array}{l}\text { External workers have } \\
\text { strong interest in working } \\
\text { for the company }\end{array}$ & 0.779 & 0.027 & 0.070 & -0.006 & -0.028 & 0.000 \\
\hline $\begin{array}{l}\text { Company is attractive for } \\
\text { the talents }\end{array}$ & 0.186 & 0.085 & -0.273 & 0.140 & -0.046 & 0.305 \\
\hline $\begin{array}{l}\text { New employees are } \\
\text { recruited only in } \\
\text { exceptional cases }\end{array}$ & 0.079 & 0.804 & 0.067 & -0.034 & -0.120 & 0.131 \\
\hline $\begin{array}{l}\text { Employee development } \\
\text { minimised the costs in the } \\
\text { company }\end{array}$ & -0.077 & -0.121 & -0.844 & 0.097 & -0.013 & -0.007 \\
\hline $\begin{array}{l}\text { Employee development } \\
\text { enhanced trust between } \\
\text { managers and staff in the } \\
\text { company }\end{array}$ & -0.169 & -0.055 & 0.223 & -0.037 & 0.725 & -0.041 \\
\hline $\begin{array}{l}\text { Employee development } \\
\text { enhanced the employee } \\
\text { loyalty in the company }\end{array}$ & -0.064 & -0.025 & -0.101 & 0.879 & -0.057 & 0.025 \\
\hline $\begin{array}{l}\text { Employee development } \\
\text { lowered the employee } \\
\text { turnover in the company }\end{array}$ & 0.027 & 0.080 & 0.014 & -0.077 & -0.009 & 0.798 \\
\hline $\begin{array}{l}\text { Employee development } \\
\text { enhanced overall } \\
\text { performance in the } \\
\text { company }\end{array}$ & -0.019 & 0.710 & 0.089 & -0.022 & 0.266 & -0.025 \\
\hline $\begin{array}{l}\text { Employee development } \\
\text { enhanced competitiveness } \\
\text { in the company }\end{array}$ & 0.087 & -0.064 & 0.035 & 0.850 & -0.011 & -0.118 \\
\hline Total \% of Variance & 8.874 & 8.231 & 7.442 & 6.941 & 5.965 & 5.502 \\
\hline Name of factor & $\begin{array}{c}\text { External } \\
\text { orientation }\end{array}$ & $\begin{array}{c}\text { Internal } \\
\text { development }\end{array}$ & $\begin{array}{l}\text { Investment } \\
\text { in HR }\end{array}$ & Loyalty & Coherence & $\begin{array}{c}\text { Talent } \\
\text { management }\end{array}$ \\
\hline
\end{tabular}

Source: own survey 
The results obtained confirm that current constant development of employee enhancement is crucial in agriculture and that all employees of these agricultural companies including lowskilled, engineering and technical positions have to focus on development of the competencies, skills and qualification, which is in compliance with Xinyu et al. (2015). Each sector, including agriculture, needs to invest in employee development, thus developing entire company. Employee development in agricultural companies may eliminate the problems resulting from the drain of reliable employees. The views of Kim and Winnings (2011) that human resource policy should respond to rapidly changing demographics (number of older people in agriculture, lack of young people in agriculture etc.) can be accepted. The results achieved allow confirming the impact of the employee development on commitment and performance including loyalty, which is in compliance with Green (2008) or Brown et al. (2011).

Taking into account the results achieved it can be summarised that each of the agricultural companies addressed should have the employees of the quality needed by the company to achieve its goals and that the company management need to support external orientation, internal development, investment in HR, loyalty, coherence and talent management.

\section{CONCLUSION}

The paper focuses on specific area of agriculture, facing lack of qualified labour force and young employees. Thus the practical contribution of the paper is the presentation of the results focused on employee development in these companies with an emphasis on application of the HR strategy of talent management.

The theoretical contribution of this paper concerns the categorisation of employee development systems in agricultural employment. Employee development has been recognised as being important to mutually align employer and employee needs in the employment relationship and fostering commitment, loyalty and performance. The results were able to classify the HR systems of the case organisations into six types according to factor analysis: First, oriented on external HR marketing, second oriented inside on employee development, third expressing costs and investments into employee development, fourth described by enhanced loyalty and competitiveness based on employee development; fifth described by increased understanding and loyalty and finally, the link to talent and increased retention, loyalty and commitment of employees was perceived based on employee development.

Based on the results, we may support the theory in the statement that employee development significantly impacts employee loyalty, commitment and performance. Surveyed companies perceive all mentioned benefits of employee development and analysis confirmed significant relationships. Furthermore, smaller companies such as the farms surveyed here often lack formal rules and regulations. On the contrary, large companies have exact practices and outputs related to it. As we have shown, such institutional directions on employment management practice should be understood as a dynamic product of the duality of structure, and it is necessary to work with employee development in order to achieve desired positive impacts. Following the findings in Czech agricultural companies, employee development systems are still on its early stage and rising, but companies see benefits related to it. The key to changing this unstructured system lies in creating structural steps and processes that support employee transformation, such as talent pools, talent management, development plans including budgets aligned with channels for communication to employees and also employers in the sector. Summarising, the value of an approach in examining employee development systems in Czech agriculture concerns its simultaneous sensitivity to context and to current demography and expectations of workers on labour market. Structuration theory provides a dynamic framework to account for observed heterogeneity, which is worthwhile to deeper analysis in future research.

\section{REFERENCES}

AKERLOF, G. A. and KRANTON, R. E. 2005. Identity and the Economics of Organizations. Journal of Economic Perspectives, 19(1): 9-32.

ANDERSON, V. 2009. Research Method in Human Resource Management. $2^{\text {nd }}$ Edition. London: Chartered Institute of Personnel Development.

APPELBAUM, E. and SCHMITT, J. 2009. Low-wage work in high-income countries: labour-market institutions and business strategy in the US and Europe. Human Relations, 62(12): 1907-1934.

BARAO, A., DE VASCONCELOS, J. B., ROCHA, Á. and PEREIRA, R. 2017. A knowledge management approach to capture organizational learning networks. International Journal od Information Management, 37(6): 735-740.

BARRETT, R. and RAINNIE, A. 2002. What's so special about small firms? Developing an integrated approach to analysing small firm industrial relations. Work, Employment and Society, 16(3): 415-434. 
BROWN, S., MCHARDY, J., MCNABB, R. and TAYLOR, K. 2011. Workplace Performance, Worker Commitment, and Loyalty. Journal of Economics $\sigma$ Management Strategy, 10(3): 925-955.

DE VAUS, D. 2014. Surveys in social research. $6^{\text {th }}$ Edition. Abingdon, Oxon: Routledge, Studies in Society.

DIAZ-FERNANDEZ, M., PASAMAR-REYES, S. and VALLE-CABRERA, R. 2017. Human capital and human resource management to achieve ambidextrous learning: A structural perspective. BRQ Business Research Quarterly, 20(1): 63-77.

EDWARDS, P. and RAM, M. 2006. Surviving on the margins of economy: working relationships in small, low-wage firms. Journal of Management Studies, 43(4): 895-916.

EDWARDS, P., SENGUPTA, S. and TSAI, C. 2009. Managing low-skill workers: a study of UK food manufacturing firms. Human Resource Management Journal, 19(1): 40-58.

GARAVAN, T. N., CARBERY, R. and ROCK, A. 2012. Mapping talent development: definition, scope and architecture. European Journal of Training and Development, 36(1): 5-24.

GAUTHIÉ, J. and SCHMITT, J. 2010. Low-Wage Work in the Wealthy World. New York: Russell Sage Foundation.

GRIFFITH, R. and SIMPSON, H. 2004. Characteristics of Foreign-Owned Firms in British Manufacturing. IFS Working Paper No. W01/10. Institute for Fiscal Studies.

HEBÁK, P. et al. 2014. Statistické myšlení a nástroje analýzy dat. Praha: Informátorium.

HELD, J. 2016. Benefit trends: benefits a big part of compensation. Benefits Magazine, 53(7): 8-10.

HENDL, J. 2012. Pŕehled statistických metod: analýza a metaanalýza dat. $4^{\text {th }}$ Edition. Praha: Portál.

HUGHES J. C. and ROG, E. 2008. Talent management - a strategy for improving employee recruitment, retention and engagement within hospitality organizations. International Journal of Contemporary Hospitality Management, 20(7): 743-757.

JANSSEN, B. 2013. Herd Management: Labor Strategies in Local Food Production. Anthropology of Work Review, 34(2): 68-79.

KIM, J. and WIGGINS, M. E. 2011. Family-Friendly Human Resource Policy: Is It Still Working in the Public Sector? Public Administration Review, 71(5): 728-739.

KNOX, A. and WALSH, J. 2005. Organisational flexibility and HRM in the hotel industry: evidence from Australia. Human Resource Management Journal, 15(1): 57-75.

KRAGULJ,F.2016. ConceptualisingNeedstoEnhance OrganisationalLearning and EnableKnowledge-Based Innovation. Procedia Computer Science, 99: 225-242.

KROON, B. and PAAUWE, J. 2014. Structuration of precarious employment in economically constrained firms: the case of Dutch agriculture. Human Resource Management Journal, 24(1): 19-37.

LEE, C. H. and BRUVOLD, N. T. 2003. Creating Value for Employees: Investment in Employee Development. International Journal of Human Resource Management, 14(6): 981-1000.

LI, D. Y. and LIU, J. 2014. Dynamic capabilities, environmental dynamism, and competitive advantage: Evidence from China. Journal of Business Research, 67(1): 2793-2799.

MARCHINGTON, M. 2015. Human resource management (HRM): Too busy looking up to see where it is going longer term? Human Resource Management Review, 25(2): 176-187.

MEYER, J. P., ALLEN, N. J. 1991. A Three-Component Conceptualization of Organizational Commitment. Human Resource Management Review, 1: 61-89.

MEYER, J. P., STANLEY, D. J., HERSCOVITCH, L. and TOPOLNYTSKY, L. 2002. Affective, Continuance, and Normative Commitment to the Organization: A Meta-Analysis of Antecedents, Correlates, and Consequences. Journal of Vocational Behavior, 61(1): 20-52.

MUNDAY, M., PEEL, M. and TAYLOR, K. 2003. The Performance of the Foreign-Owned Sector of UK Manufacturing: Some Evidence and Implications for UK Inward Investment Policy. Fiscal Studies, 24: 501-521.

PALÁT, M. 2012. Statistical data processing [In Czech: Statistické zpracování dat]. [Online]. Available at: http:// www.vuchs.cz/OPVpK/dokumenty/Palat-Statistika-2.pdf [Accessed: 2016, March 03].

PENA, A. A. 2010. Poverty, legal status and pay basis: the case of U. S. agriculture. Industrial Relations, 49(3): 429-454.

RASTGOO, P. 2016. The Role of Human Resources Competency in Improving the Manager Performance. Acta Universitatis Agriculturae et Silviculturae Mendelianae Brunensis, 64(1): 341-350.

RAZAK, N. A., PANGIL, F., ZIN, M. L. M., YUNUS, N. A. M. and ASNAWI, N. H. 2016. Theories of Knowledge Sharing Behavior in Business Strategy. Procedia Economics and Finance, 37(1): 545-553.

ROWAN, J. R. 2000. The moral foundation of employee rights. Journal of Business Ethics, 24(4): 355-361.

SCHULER, R. S. and JACKSON, S. E. 1987. Linking competitive strategies with human resource management practices. Academy of Management Executive, 1(3): 207-219.

SEUNEKE, P., LANS, T., WISKERKE, J. S. C. 2013. Moving beyond entrepreneurial skills: Key factors driving entrepreneurial learning in multifunctional agriculture. Journal of Rural Studies, 32: 208-219.

SIMMONS, J. 2008. Ethics and morality in human resource management. Social Responsibility Journal, 4(1/2): $8-23$.

ŠÜMANE, S., KUNDA, I., KNICKEL, K. et al. 2017. Local and farmers' knowledge matters! How integrating informal and formal knowledge enhances sustainable and resilient agriculture. Journal of Rural Studies, 59: 232-241. 
WILDEN, R., GUDERGAN, S. and LINGS, I. 2010. Employer branding: Strategic implications for staff recruitment. Journal of Marketing Management, 26(1-2): 56-73.

XINYU,Z., QINGBAO, P., PENGFEI, G. and JINLONG, G. 2015. Research on Agricultural Water Conservancy Engineering Applied Talents Cultivation System. SHS Web of Conferences, 14:0200.

Hana Urbancová: urbancova.hana@uzei.cz Lucie Vnoučková:lucie.vnouckova@vsem.cz 